\title{
Advances in the use of nanocarriers for cancer diagnosis and treatment
}

\author{
Avanços na utilização de nanocarreadores no tratamento e no diagnóstico de câncer
}

Débora Braga Vieira ${ }^{1}$, Lionel Fernel Gamarra ${ }^{1}$

\begin{abstract}
The use of nanocarriers as drug delivery systems for therapeutic or imaging agents can improve the pharmacological properties of commonly used compounds in cancer diagnosis and treatment. Advances in the surface engineering of nanoparticles to accommodate targeting ligands turned nanocarriers attractive candidates for future work involving targeted drug delivery. Although not targeted, several nanocarriers have been approved for clinical use and they are currently used to treat and/or diagnosis various types of cancers. Furthermore, there are several formulations, which are now in various stages of clinical trials. This review examined some approved formulations and discussed the advantages of using nanocarriers in cancer therapy.
\end{abstract}

Keywords: Nanomedicine; Liposomes; Nanoparticles; Neoplasms/drug therapy; Drug delivery systems

\section{RESUMO}

A utilização de nanocarreadores como sistemas de entrega de drogas para agentes terapêuticos ou de imagem pode aumentar as propriedades farmacológicas dos compostos normalmente utilizados no tratamento e diagnóstico de câncer. Avanços em engenharia de superfície de nanopartículas para a acomodação de ligantes alvo têm feito dos nanocarreadores candidatos atrativos para um futuro trabalho envolvendo entrega de droga direcionada. Embora não direcionados, muitos nanocarreadores terapêuticos foram aprovados para uso clínico no tratamento e/ou diagnóstico de vários tipos de câncer. Além disso, há várias outras formulações que se encontram agora em estágio de testes clínicos. Este artigo de revisão examinou algumas formulações aprovadas e discutiu as vantagens da utilização de nanocarreadores na terapia de câncer.

Descritores: Nanomedicina; Lipossomos; Nanopartículas; Neoplasias/ quimioterapia; Sistemas de liberação de medicamentos

\section{INTRODUCTION}

Chemotherapeutic drugs are toxic against cancer cells, but due to their low specificity and high toxicity, these drugs are also toxic for healthy cells. This toxic reaction occurs because medications, in general, are small enough molecules to pass through the endothelium in almost all regions of the organism after systematical administration, and they can reach both target regions and other regions not affected by the disease, therefore, originating a number of side effects associated with the medication. A possible strategy that may improve therapeutic efficacy of chemotherapeutic agents and decrease its side effects entails the use of colloidal nanoparticle systems. Because these drugs are encapsulated within nanoparticles of $50-800 \mathrm{~nm}$, they are not possible to cross the vessel wall of healthy regions of the organism (the space between these cells is only $15-30 \mathrm{~nm}$ ). This is different from what occurs in inflamed regions or even in those regions where tumors are located, in which endothelial cells are less packed among themselves than in healthy regions, which result in an accumulation of nanoparticles in the tumor tissue near blood vessel ${ }^{(1-3)}$ (Figure 1A). This vectorization strategy is known as enhanced permeability and retention effect (EPR). ${ }^{(4)}$

Surface of nanoparticles can be easily modified, allowing to direct nanocarriers to specific cancer cells with action mechanism based on expressive molecules in the surface of the tumor, which result in active directing of these particles (Figure 1A). Molecules such

\footnotetext{
${ }^{1}$ Hospital Israelita Albert Einstein, São Paulo, SP, Brazil.

Corresponding author: Lionel Fernel Gamarra - Avenida Albert Einstein, 627/701 - Morumbi - Zip code: 05652-900 - São Paulo, SP, Brazil - Phone: (55 11) 2151-0243 E-mail: lionelgamarra7@gmail.com

Received on: Aug 19, 2015 - Accepted on: Nov 23, 2015

DOI: 10.1590/\$1679-45082016RB3475
} 


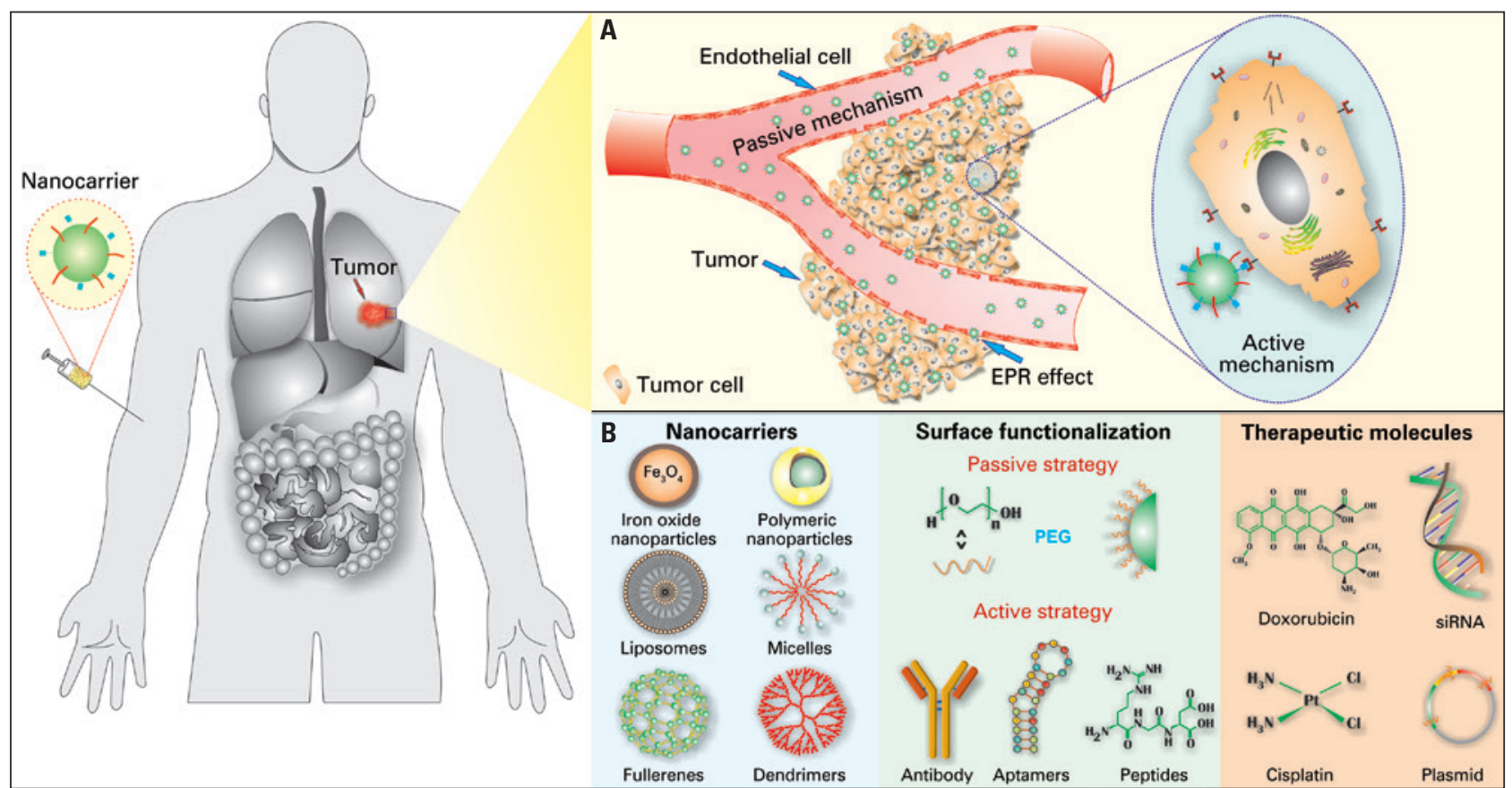

EPR: enhanced permeability and retection; PEG: polyethylene glycol.

Figure 1. Nanocarriers for cancer treatment. (A) Nanocarriers can be accumulated in the tumor through a passive mechanism known as EPR effect, because of the increased vascular permeability in the tumor region. Additionally, the active mechanism also increase nanoparticles uptake by tumor cells. This mechanism comprises in changes on the surface of nanocarriers with molecules that can be recognized specifically by receptors on the surface of cell membrane. (B) Examples of nanocarriers surface ligands and therapeutic agents used for cancer diagnosis or treatment

as antibodies, peptides and RNA aptamers, and others (Figure 1B) are widely used to direct nanoparticles. ${ }^{(5)}$ Still, the use of these nanostructure has a variety of advantages in relation to free administration of medication, and one of these advantages are: (i) protection of medication against degradation in the organism, (ii) better absorption of the drug in tumor tissue, and (iii) change in the medication's pharmacokinetic, among others.

Currently, a number of nanoparticles have been approved by the US Food and Drug Administration $(\text { FDA })^{(6-14)}$ (Figure 2), which accumulate in solid tumors because of the EPR effect. ${ }^{(2,3)}$ Among approved ones, the highlighted are liposomal doxorubicin, the Doxil ${ }^{\circledR}$, which was the one of the first medication based on nanotechnology approved by FDA. ${ }^{(6)}$ Another example is the Abraxane ${ }^{\circledR}$, the paclitaxel, a chemotherapy drug, which is efficiently associated with nanoparticle called albumin. This formulation was approved by FDA in 2005 for breast cancer treatment, and in 2013 to treat pancreas cancer. ${ }^{(11-14)}$ Other examples of these nanostructured medicines to treat and diagnose cancer are shown in timeline in the figure 2.

Literature has several epidemiologic studies and pre-clinical tests showing the great potential of new medications either synthetic and from natural- source compounds against cancer (Table 1). These new macromolecules include peptides, proteins, oligonucleotides, plasmids and, more recently, inhibition of specific expression of gene silencing by RNA interference ${ }^{(3,15-17)}$ (Figure 1B). However, despite the great advances in science and technology to obtain new medications, pioneer pharmaceutical companies are stopping the production of new synthetic drugs to produce generic drugs, particularly after these medications patent have expired. The development of new medications is costly, particularly the synthetic routes. ${ }^{(3)}$ This scenario creates the need of presenting conventional chemotherapy drugs in new formulations which can be a new delivery system or development of new use for the existing medications, such as the case of chloroquine and their analogues, which are used for malaria treatment. And, currently, they are on trial for treatment of several types of cancer. ${ }^{(18)}$

This review discusses some scientific advances related with the use of nanoparticles for cancer diagnosis and treatment. We performed the search in PubMed and Web of Science. The keywords used were "nano" AND "cancer" combined with "FDA approved" and the 'search' all fields. We included only articles written in English. We selected study based on number of citations and/or year of publication. 


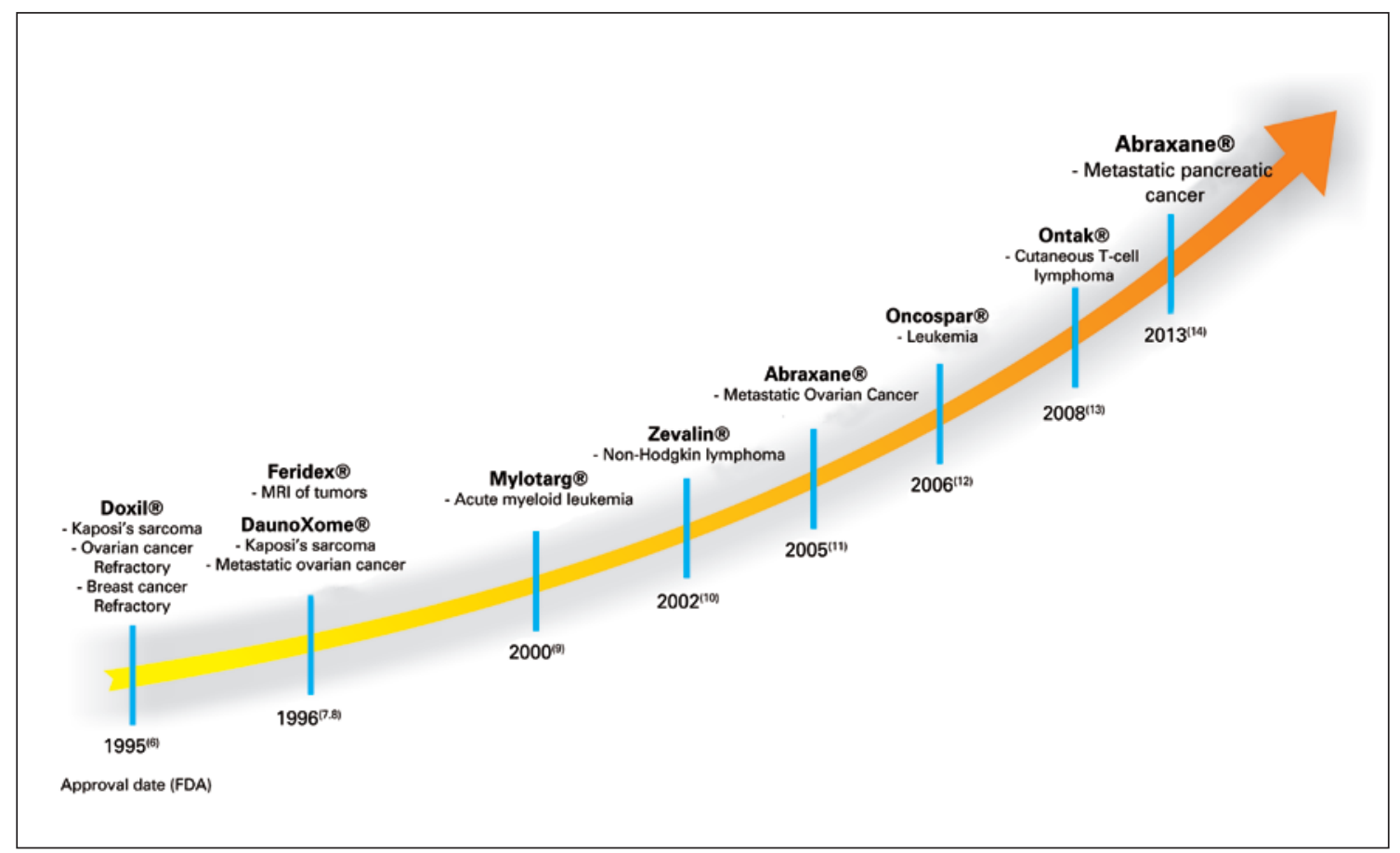

FDA: Food and Drug Administration.

Figure 2. Timeline with some examples of nanoparticles approved by Food and Drug Administration. ${ }^{(6-14)}$ Doxil $^{\circledR}$ is the liposomal doxorubicin formulation; Feridex ${ }^{\circledR}$ includes superparamagnetic iron nanoparticles associated with dextran, DaunoXome ${ }^{\circledR}$ is the liposomal daunorubicin, Mylotarg ${ }^{\circledR}$ has gemtuzumab ozogamicin molecules bonded to monoclonal antibody, Zevalin ${ }^{\circledR}$ includes mouse monoclonal antibody lgG1 with tiuxetan chelator associated with radioactive isotope Yttrium-90, Abraxane ${ }^{\circledR}$ has paclitaxel bonded to albumin; Oncaspar ${ }^{\circledR}$ is the modified version of the L-asparaginase enzyme, and Ontak ${ }^{\circledR}$ includes the fusion protein denileukin diftitox

Table 1. Therapeutic nanoparticles under clinical trials

\begin{tabular}{|c|c|c|c|c|c|c|c|}
\hline Phase & Nanodrug & Type of cancer & Patients (n) & Start date & End date & Country & Study ID number \\
\hline IV & $\begin{array}{l}\text { Pegylated liposomal doxorubicin } \\
\qquad\left(\text { Doxil }{ }^{\mathbf{B}}\right)\end{array}$ & Ovary cancer & 58 & November 2004 & January 2008 & Russia & NCT00727961 \\
\hline$|/| \mid$ & $\begin{array}{l}\text { Gemzar }^{\circledR} \text { mix with compound } \\
\text { Glycyrrhizin Injection }\end{array}$ & Pancreas cancer & 60 (estimative) & May 2015 & Ongoing & United States & NCT02449135 \\
\hline$\|$ & $\begin{array}{l}\text { Cyclodextrin-containing } \\
\text { camptothecin }\end{array}$ & Lung cancer (recurrent) & 156 (estimative) & February 2013 & Ongoing & United States & NCT01803269 \\
\hline- & $\begin{array}{l}\text { Cyclodextrin-containing } \\
\text { camptothecin }\end{array}$ & $\begin{array}{l}\text { Metastatic stomach, } \\
\text { gastroesophageal, or } \\
\text { esophageal cancer }\end{array}$ & 10 & June 2012 & June 2015 & United States & NCT01612546 \\
\hline IV & $\begin{array}{l}\text { Polymeric micelle containing } \\
\text { paclitaxel }\end{array}$ & Breast cancer (recurrent) & 90 (estimative) & May 2009 & Ongoing & South Korea & NCT00912639 \\
\hline$\|$ & Magnesium oxide nanoparticles & Breast cancer & 288 & September 2011 & August 2013 & United States & NCT01439945 \\
\hline$\|$ & PEG-Irinotecan (NKTR 102) & Lung cancer & 38 (estimative) & August 2013 & Ongoing & United States & NCT01876446 \\
\hline$|/| \mid$ & $\begin{array}{l}\text { Lipid nanoparticles } \\
\text { containing siRNA }\end{array}$ & Liver cancer & 72 (estimative) & December 2014 & Ongoing & United States & NCT02314052 \\
\hline$\|$ & $\begin{array}{l}\text { Block copolymer vaccine } \\
\text { containing peptides }\end{array}$ & Melanoma & 48 & March 1998 & November 2002 & United States & NCT00003274 \\
\hline
\end{tabular}

PEG: polyethylene glycol.

\section{Nanomedicines for cancer: state-of-the-art}

One of the basics of nanomedicine is to delivery medications in a specific and efficient way to the site of the disease. In general, this can be achieved by different ways of administration, such as oral, nasal, transdermal, intravenous, among others. In many cases, however, the efficacy of the medication can be improved and side effects reduced by encapsulation or association to some type of nanoparticle. The main nanoparticles described in the literature are iron oxide, gold, polymeric, liposomes, micelles, fullerenes, carbon nanotubes, graphene, dendrimers, quantum dots, nanodiamonds, 
among others. Some examples of these nanocarriers are described in figure $1 \mathrm{~B} . .^{(2,3,19,20)} \mathrm{Next}$, we describe the main nanoparticles study for carrier and controlled release of medication as well as a brief report of nanocarriers current status of clinical development.

Polymeric nanoparticles are the most study particles for carrier a number of therapeutic molecules particles because of their excellent biocompatibility and biodegradability, in addition of not being toxic and non-immunogenic. They constitute a diverse class of nanocarriers because depend on the polymer that constitute them and on their surface load, they present different proprieties. Several synthetic polymers including poly (lactic acid), poly (lactic-co-glycolic acid) or polyethyleneimine, or natural, such as chitosan, collagen, gelatin or albumin, which are used to produce polymeric nanoparticles. ${ }^{(21,22)}$ One of the first studies on the use of polymeric nanoparticles for the use of cancer was reported in 1979 when Couvreur et al. developed a simple method to produce nanoparticles of poly (alkyl cyanoacrylate). ${ }^{(23)}$ Since then, nanoparticles of this polymer are intensively studied for carrier and delivery of a variety of anticancer drugs. ${ }^{(24)}$ Their study definitely contribute for the development of doxorubicin nanoparticles, which is current in phase III clinical trial. ${ }^{(25)}$ In addition, albumin nanoparticles $\left(\right.$ Abraxane $\left.^{\circledR}\right)$ have been approved by FDA for chemotherapy transportation for different types of cancer treatment. ${ }^{(11,14)}$

Amphiphilic carriers also have biologic attractive proprieties as biocompatibility, biodegradability and drug isolation of the surrounding medium, and the ability of carrier both hydrophilic and hydrophobic drugs. Liposomes, polymeric vesicles and micelles belong to the class of amphiphilic carriers (Figure 1B). Formation of liposomes results of the self-assembly of lipid molecules in aqueous solution, and they are simply closed bilayers that delimitate an internal aqueous compartment. Liposomes were the first nanocarriers approved by regulatory agencies for carrier several chemotherapeutic agents. ${ }^{(26,27)}$ As already described here, the first formulation of liposomes to be approved in the market was the Doxil ${ }^{\circledR}$ in 1955 for treatment of Kaposi sarcoma associated with AIDS. Other formation of liposomes for cancer treatment are also available in the market, such as the DaunoXome ${ }^{\circledR}$. $^{(7)}$

Polymeric vesicles, also known as polymersomes, have a similar architecture to liposomes, since they are composed of synthetic amphiphilic polymers that have similar structure of lipids. ${ }^{(28)}$ However, we did not find any study in the literature describing clinical studies for this type of structure. Furthermore, micelles are molecular aggregates that have both hydrophilic and hydrophobic structural regions that are dynamically and spontaneously associated in aqueous solution up to a specific critical concentration. Micelles have been successful used as transporters of hydrophobic drugs. ${ }^{(29)}$ An example is the approval by FDA of the Genexol-PM for breast cancer treatment. ${ }^{(30)}$

Still, there is a number of technologies involved in the development of nanocarrier including in its chemical, physical and biological properties. For example, vectors that overcome biologic barriers, targets for cancer, releasing for the brain, combination of potential targets with antibodies with technologies and nanoparticles. However, despite several efforts towards nanocarriers, to choose the most adequate nanocarrier is not obvious for a variety of reasons that can simultaneously affect the biodistribution and target of nanocarriers. Oncologists in the near future should have specific combinations of nanocarriers and target molecules - similar to the strategies of chemotherapy combination that can be personalized to improve treatment against cancer - that will contribute to improve therapeutic results and reduce costs. These combinations will represent an important modality for cancer diagnosis and treatment.

\section{ACKNOWLEDGMENTS}

We thank Instituto Israelita de Ensino e Pesquisa Albert Einstein (IIEPAE), Conselho Nacional de Desenvolvimento Científico e Tecnológico (CNPq), Financiadora de Estudos e Projetos (FINEP), Coordenação de Aperfeiçoamento de Pessoal de Nivel Superior (CAPES), and Fundação de Amparo à Pesquisa do Estado de São Paulo (FAPESP), for funding this study.

\section{REFERENCES}

1. Khawar IA, Kim JH, Kuh HJ. Improving drug delivery to solid tumors: priming the tumor microenvironment. J Control Release. 2015;201:78-89. Review.

2. Peer D, Karp JM, Hong S, Farokhzad OC, Margalit R, Langer R. Nanocarriers as an emerging platform for cancer therapy. Nat Nanotechnol. 2007;2(12):751-60. Review.

3. Allen TM, Cullis PR. Drug delivery systems: entering the mainstream. Science. 2004;303(5665):1818-22.

4. Matsumura $Y$, Maeda H. A new concept for macromolecular therapeutics in cancer- chemotherapy: mechanism of tumoritropic accumulation of proteins and the antitumor agent smancs. Cancer Res. 1986;46(12 Pt 1):6387-92.

5. Pérez-Herrero E, Fernández-Medarde A. Advanced targeted therapies in cancer: drug nanocarriers, the future of chemotherapy. Eur J Pharm Biopharm. 2015:93:52-79. Review.

6. Northfelt DW, Martin FJ, Working P, Volberding PA, Russell J, Newman M, et al Doxorubicin encapsulated in liposomes containing surface-found polyethylene glycol: pharmacokinetics, tumor localization, and safety in patients with AIDSrelated Kaposi's sarcoma. J Clin Pharmacol. 1996;36(1):55-63.

7. Presant CA, Scolaro M, Kennedy P, Blayney DW, Flanagan B, Lisak J, et al. Liposomal daunorubicin treatment of HIV-associated Kaposi's sarcoma. Lancet. 1993:341(8855):1242-3. 
8. Reimer P, Tombach B. Hepatic MRI with SPIO: detection and characterization of focal liver lesions. Eur Radiol. 1998;8(7):1198-204. Review.

9. Bross PF, Beitz J, Chen G, Chen XH, Duffy E, Kieffer L, et al. Approval summary: gemtuzumab ozogamicin in relapsed acute myeloid leukemia. Clin Cancer Res. 2001;7(6):1490-6. Erratum in: Clin Cancer Res. 2002;8(1):300.

10. Theuer CP, Leigh BR, Multani PS, Allen RS, Liang BC. Radioimmunotherapy of non-Hodgkin's lymphoma: clinical development of the Zevalin regimen. Biotechnol Annu Rev. 2004;10:265-95. Review.

11. Gradishar WJ. Albumin-bound paclitaxel: a next-generation taxane. Expert Opin Pharmacother. 2006;7(8):1041-53. Review.

12. Dinndorf PA, Gootenberg J, Cohen MH, Keegan P, Pazdur R. FDA drug approval summary: pegaspargase (oncaspar) for the first-line treatment of children with acute lymphoblastic leukemia (ALL). Oncologist. 2007;12(8):991-8.

13. Lansigan F, Stearns DM, Foss F. Role of denileukin diftitox in the treatment of persistent or recurrent cutaneous T-cell lymphoma. Cancer Manag Res. 2010;2:53-9.

14. Saif MW. U.S. Food and Drug Administration approves paclitaxel protein-bound particles (Abraxane ${ }^{\circledR)}$ in combination with gemcitabine as first-line treatment of patients with metastatic pancreatic cancer. JOP. 2013;14(6):686-8.

15. Whitehead KA, Langer $R$, Anderson DG. Knocking down barriers: advances in siRNA delivery. Nat Rev Drug Discov. 2009;8(2):129-38. Review. Erratum in: Nat Rev Drug Discov. 2009;8(6):516.

16. Zhan C, Li C, Wei X, Lu W, Lu W. Toxins and derivatives in molecular pharmaceutics: drug delivery and targeted therapy. Adv Drug Deliv Rev. 2015;90:101-18. Review.

17. Dobrovolskaia MA, McNeil SE. Strategy for selecting nanotechnology carriers to overcome immunological and hematological toxicities challenging clinical translation of nucleic acid-based therapeutics. Expert Opin Drug Deliv. 2015; 12(7):1163-75.

18. Solomon VR, Lee H. Chloroquine and its analogs: a new promise of an old drug for effective and safe cancer therapies. Eur J Pharmac. 2009;625(1-3): 220-33. Review.
19. Coelho SC, Pereira MC, Juzeniene A, Juzenas P, Coelho MA. Supramolecular nanoscale assemblies for cancer diagnosis and therapy. J Control Release. 2015;213:152-167. Review.

20. Gharpure KM, Wu SY, Li C, Lopez-Berestein G, Sood AK. Nanotechnology: future of oncotherapy. Clin Cancer Res. 2015;21(14):3121-30. Review.

21. Duncan R. Polymer conjugates as anticancer nanomedicines. Nat Rev Cancer. 2006;6(9):688-701. Review.

22. Kaur S, Prasad C, Balakrishnan B, Banerjee R. Trigger responsive polymeric nanocarriers for cancer therapy. Biomater Sci. 2015;3(7):955-87.

23. Couvreur P, Kante B, Lenaerts V, Scailteur V, Roland M, Speiser P. Tissue distribution of anti-tumor drugs associated with polyalkylcyanoacrylate nanoparticles. J Pharm Sci. 1980;69(2):199-202.

24. Couvreur P, Kante B, Grislain L, Roland M, Speiser P. Toxicity of polyalkylcyanoacrylate nanoparticles II: Doxorubicin-loaded nanoparticles. J Pharm Sci. 1982;71(7):790-2.

25. Le Droumaguet B, Nicolas J, Brambilla D, Mura S, Maksimenko A, De Kimpe $\mathrm{L}$, et al. Versatile and efficient targeting using a single nanoparticulate platform: application to cancer and Alzheimer's disease. ACS Nano. 2012; 6(7):5866-79.

26. Gabizon AA. Stealth liposomes and tumor targeting: one step further in the quest for the magic bullet. Clin Cancer Res. 2001;7(2):223-5.

27. Safra T, Muggia F, Jeffers S, Tsao-Wei DD, Groshen S, Lyass 0 , et al Pegylated liposomal doxorubicin (doxil): reduced clinical cardiotoxicity in patients reaching or exceeding cumulative doses of $500 \mathrm{mg} / \mathrm{m} 2$. Ann Oncol. 2000;11(8):1029-33

28. Tanner P, Baumann P, Enea R, Onaca O, Palivan C, Meier W. Polymeric vesicles: from drug carriers to nanoreactors and artificial organelles. Acc Chem Res. 2011;44(10):1039-49. Review.

29. Jhaveri AM, Torchilin VP. Multifunctional polymeric micelles for delivery of drugs and siRNA. Front Pharmacol. 2014;5(77):1-26.

30. Oerlemans C, Bult W, Bos M, Storm G, Nijsen JF, Hennink WE. Polymeric micelles in anticancer therapy: targeting, imaging and triggered release. Pharm Res. 2010;27(12):2569-89. Review. 